\title{
IMPACT OF TOTAL PRODUCTIVE MAINTENANCE METHODOLOGY ON THE PERFORMANCE
}

\author{
Mahmoud Mohamed A. Sayed \\ Mechanical Engineering Department, Canadian International College, Egypt \\ m_m_sayed@cic-cairo.com
}

\begin{abstract}
These days, the organization and companies meet a lot of challenges(internally: to increase the performance, and externally: market share). This work focuses on the internal challenges: such as performance.The most important pillars of the production operations are employees, machines, equipment's, and etc. Maintenance represents the important activity that makes the machines and equipment's operate efficiently. Companies attempt to increase performance and minimize production costs by using a certain approach such as Total productive maintenance (TPM). This work introduces a methodology to improve the performance (operator and equipment) throughproposed model of TPM. Also, it indicates the importance of maintenance which minimizes or eliminates the production problems and increases the organizational productivity.
\end{abstract}

Keywords:Maintenance, Maintenance Management System (MMS), Maintenance Office (MO), Preventive Maintenance (PM), Total productive maintenance (TPM), andOverall Equipment Effectiveness (OEE).

\section{INTRODUCTION}

TPM can be considered the science of machinery health. TPM was introduced to achieve some objectives such as: avoid waste, reduce cost, energy optimization[1]. Maintenance is the combination of all technical, administrative and managerial actions during the life cycle of an item which, it can perform the required function [2]. Predictive intelligence maintenance increases the performance by detecting and diagnosing potential equipment problems before they grow reducing the frequency and cost ofrepairs.TPM investigate to involve operators in all departments and levels. [3].

This work indicatesrole of maintenance which has great impact on the equipment life and presents TPMas a methodology (tosave time, and increase the performance throughout planned maintenance). Also, it defined TPM as a system of integration and coordination between resources at all levels to avoid or eliminate breakdown or waste.

\section{WHY TOTAL PRODUCTIVE MAINTENANCE}

The main objective is to effectively manage available sources (people, equipment, money, time, and etc.) to operate a facility with efficient method.TPM attempts to improve the integrity of production resources that add business value. Applying TPM as a Methodology is to increase OEE of equipment's through:

- Maintenance management system (MMS)

- Emphases on preventive maintenance

- Overall equipment effectiveness (OEE)

\subsection{Maintenance Management System}

The term 'maintenance' covers many activities; including inspection, testing, and measurement ...It has a vital role to play in eliminating workplace hazards and providing safer and healthier working conditions [4]. Maintenance may cause small barrier for production, but that is nothing compared to actual downtime caused by a breakdown. PM procedures take less time than emergency repairs and replacements [5].

This work buildsMMSas a technique to manage the resources related to maintenance issues, which increases the performance and avoids some problems such as: breakdown of equipment, lack of planning, deferred maintenance (due to lack of resources).Also, ensures the role of maintenance activities throughout MMS to save effort, cost, time, and increase the performance. The main purpose of regular maintenance is to ensure all equipment's required for production as follows:

- Operating at higher efficiency (all times,through maintenanceactivities such as: inspections, cleaning, lubricating, and adjustments).

- $\quad$ Reducing the resources (raw materials, spare parts) and efforts.

- Easyto predicting the required activities such as: replacement to avoid unplanned maintenance (corrective maintenance)

There are important integrity among the maintenance, quality, and production as shown in Fig. 1. 


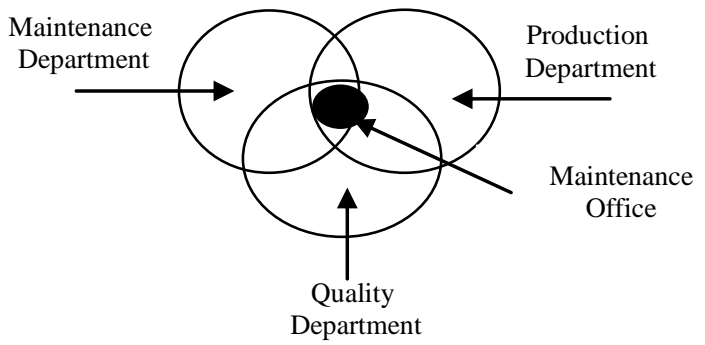

Fig. 1. Relationship AmongDepartments

It is essential to integrate between the maintenance and other departments throughout Maintenance Office (MO) such as: quality, and production. MO is cornerstone of any successful organization or company, which coordinates between all resources such as: information, data, people, equipments, budgets, and requirements of other. Some organizations and companies support MO by automated MMS to facilitate, prepare, and put all resources in suitable place on time. The main responsibilities of MO as follows:

- Gathering and collecting data or information (daily weekly - monthly - annually )

- Analysis to predict manpower, equipment and material needs (planning - scheduling).

- Predicting necessary budget for equipment and materials based on predicting or scheduling work.

- $\quad$ Planning and provide for work scheduling (monthly annually) to maintenance unit.

- Monitoringand measuring the work effort towards maintenance issues.

- $\quad$ Reporting and supporting decisions.

\subsection{Emphases On Preventive Maintenance}

In industry, there is a strong emphasis on PM which is essential for minimizing machine downtime due to breakdowns and unavailability of spare parts [6]. This work summarizes framework of PM as shown in Fig. 2.

\begin{tabular}{|c|c|}
\hline$\underset{\text { (Maintenance plan) }}{\text { Planned }}$ & $\begin{array}{c}\mathbf{P} \mathbf{M} \\
\text { (to achieve) }\end{array}$ \\
\hline $\begin{array}{c}\frac{\text { Systematic }}{\text { inspection, }} \\
\text { detection, correction,then, preve } \\
\text { ntion failure }\end{array}$ & $\begin{array}{l}\text { - Optimal resources } \\
\text { - Avoiding (breakdown } \\
\text { - repair issues) } \\
\text { (to Get) }\end{array}$ \\
\hline$\frac{\text { Essential }}{\text { To avoid deferred }}$ & $\begin{array}{l}\text { - Readiness of equipment } \\
\text { - decrease functional failure } \\
\text { - performance and efficiency }\end{array}$ \\
\hline
\end{tabular}

Fig. 2.Framework of PM

Top management must aware to support MO to execute maintenance plans (preventive maintenance) by $100 \%$ to increase the life cycle, no waste, and decrease or eliminate functional failure, consequently increase performance. PM is important activity, which must be done with any waste or loss due lack of information, or error from anybody.

\subsection{Overall Equipment Effectiveness}

TPM achieves a certain benefits such asincreasing the productivity of plant and equipment with a modest investment in maintenance. TPM designed to increase OEE of plant equipment [6]. OEE includes three factors as follows:

OEE=Performance $\mathrm{x}$ Availability $\mathrm{x}$ Quality

This work concerns TPM as a methodology which focuses on keeping all equipment's in a good condition to avoid breakdowns and troubles in the production operations. TPM has a great impact on OEE which reduce or eliminate the defects or losses in performance, quality, and availability.

\section{TPMMODEL}

TPM Modelis consists of a certain pillars, mostly focused on proactive and preventative techniques for improving equipment reliability; Autonomous maintenance, planned andquality maintenance, focused improvement, early equipment management, training and education, safety health environment, and TPM administration [7]. TPM as part of overall maintenance management evolution plays an important role for keeping all assets [8].

This work represents theproposed TPMframe model as a system, which relies on main pillars such as: training,and education, quality maintenance, plan \& organize maintenance, and evaluation \&improvement as shown inFig.3.

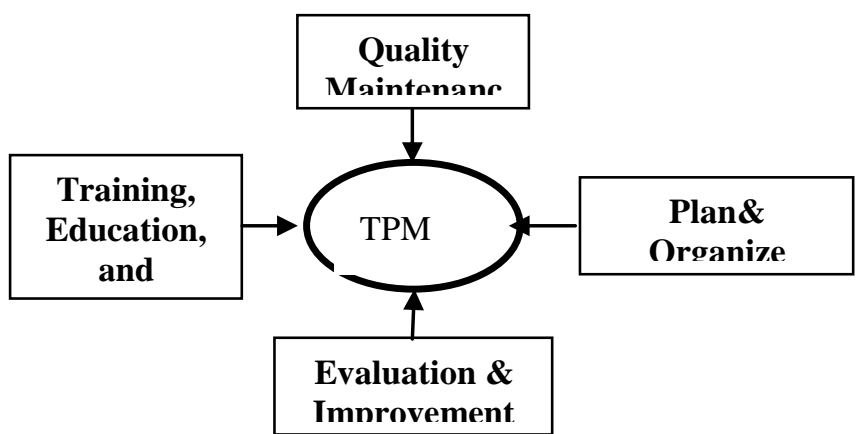

Fig. 3Proposed TPMFrame Model

Top management must designate the committee to support and evaluate the progress throughout MO. TPM committee should include production manager, maintenance manager, and quality manager.The committee should formulate TPM policies, strategies, and give advice.

\section{RESEARCH METHODOLOGY}

This work introduces a methodology to study the impact of maintenance activities throughout new technique or system (TPM model, MMS, and OM). The problems or barriers in any organization or company come from some causes as follows:

- Performance ( in all levels,....)

- Unavailability (spare parts, ....)

- Quality (No. of defects..) 
This work studies the problem that meets manufacturing company (No. of equipment breakdown, unavailability of some spare parts required for PM, production defects, number of plant accidents, cost consumed in repairs, dissatisfaction of employees, and etc... ). This work designed TPM model according to situation needed, besides MMS. Initially, evaluation and studying the available data is first step of methodology. Second, put the road map in front of top management to aware and discipline. Third, establish tools, techniques, and systems. Finally, implement, monitor and measure.

\section{IMPLEMENTATIONOF TPMMODEL}

TPM is a cross-functional technique, not a maintenance technique. It tends to be shared by maintenance and production as they are closest to the product. Losses occur due to bad scheduling or excessive setup. Any person in production cycle from the supplier to the customer will make some contribution to the performance [9].

[10], discusses the main barriers to implementation TPM, which summarized as follows:

- Lack of information about TPM

- Top management commitment

- Organization resistance to change

Many organizations fail to achieve expected performance results when implementing TPM techniques. A possible reason for the failure due tocommitment of top management, lack the knowledge, skill and suitable planning practices [11].

The proposed TPM model was implemented in manufacturing company which has ninety three machines and equipments (different types) in three production lines.Theimplementation of TPMmodel in the company is performed during three months according to the following steps: formation of TPM committee, establish the goals, put plan for TPM implementation, evaluatethe current situation, training \&education, and awareness towards TPM, andpreparation for implementation process.TPM committee should be led by a top-level executive that coordinatesbetween all implementation activities. TPM committee focuses on mostly important factors for implementation of the proposed TPM model as follows:

- Training, education, and awareness for everybody from top management to employees and workers.

- Machines and equipment's management, which indicate the role of planning and organization of maintenance, relation among machine, operator, and technical support.

- MO assignedpeople (engineers, employees, and operators) from production, maintenance, and quality departments to perform some activities as follows:

- Knowledge of machine and safety aspects

- Cleaning, inspection and lubrication standards

- General inspection skills training

- Implement and monitor to make operation easier

- Collect and analyze various data for improvements

\section{RESULTS}

The implementation of the proposed TPM model was carried out in the company throughout three months. The organization management performs an assessment after three months from the implementation, to evaluate the organization performance differences.

Some strong points sustain to successfully implementation of TPM model as follows:

- $\quad$ TPM committee and MO support MMS

- Insist of some employees (in maintenance unit) to achieve PM according the schedule (it took excessive hours)

- Integration and coordination among departments (especially, maintenance, quality, production, and etc.)

- Flow of information and data from - to departments

- Some points represent the barriers (in early stages) of implementation of TPM model as follows:

- Resistance of somebody's (during training)

- Delay of encouragement

- delay of some spare parts due to miscommunication between some departments (especially, in early stages)

The obtained results of organization assessment indicatedthat, the number of defective production, the machines and equipment breakdowns,product cycle time, and costs of machines repairing were decreased. Also, employees' and customer satisfaction were increasedimplementation of the proposed TPM model.TPM committee supports activities towards improvements, as shown in table 1 .

Table 1 Results Due toImplementation the Proposed TPM Model

\begin{tabular}{|l|l|l|l|}
\hline \multirow{2}{*}{$\begin{array}{l}\text { Assessment } \\
\text { Criteria }\end{array}$} & \multicolumn{2}{|l|}{$\begin{array}{l}\text { Implementation TPM } \\
\text { Model }\end{array}$} & $\begin{array}{l}\text { Improve- } \\
\text { ment (\%) }\end{array}$ \\
\cline { 2 - 3 } & Before & After & 72 \\
\hline $\begin{array}{l}\text { Production defects } \\
(\%)\end{array}$ & 11 & 3 & 81.25 \\
\hline $\begin{array}{l}\text { Machines } \\
\text { breakdowns (\%) }\end{array}$ & 32 & 6 & 26.2 \\
\hline $\begin{array}{l}\text { Product cycle } \\
\text { time (s) }\end{array}$ & 84 & 62 & 61.7 \\
\hline $\begin{array}{l}\text { Costs of machines } \\
\text { repair (1000 L.E) }\end{array}$ & 68.6 & 26.3 & 27.14 \\
\hline $\begin{array}{l}\text { Employees' } \\
\text { satisfaction (\%) }\end{array}$ & 70 & 89 & 33.33 \\
\hline $\begin{array}{l}\text { Customer } \\
\text { satisfaction (\%) }\end{array}$ & 66 & 88 & \\
\hline
\end{tabular}

The results in table 1 , indicated the impact from applying TPM model on the performance such as: increasing of satisfaction (employees - customer), and reduction of defects, machines breakdowns, production cycle time, and costs of machines repairs. 


\section{CONCLUSION}

Some companies and organizations are using new technique or methodology such as TPM models to improve its PMthat search about indicators to monitor, control and evaluate performance. Main objectives of companies are working towards decreases the waste, defects, and machine breakdown in order to improve the performance, customer satisfaction, and the profit. The proposed TPMmodel depends upon the main pillars such as: plan and organize maintenance that affect the successful performance of maintenance in the company.Maintenance planning and organization can increase equipment uptime, avoid serious breakdowns, improve product quality, and consequently, increase the incomes and improve the performance. This paper describes the role of MMS and MOto manage the resources related to maintenance issues, which increases the performance and avoids some problems which impact on production system.

\section{REFERENCES}

[1]. Vinay K. S., Dr. H. Ramakrishna, Ravi Kumar D. and R. Jagadeesh, "Action plans in implementing total productive energy maintenance in industry "International Journal of Innovative Research and Development, Vol. 3, Issue 6Jun. 2014, PP. 42-48.

[2]. European standard, "Maintenance Terminology", (EN)- 13306: 2001.

[3]. Ross and Associates Environmental Consulting, "Lean Manufacturing and the Environment", the U.S. Environmental Protection Agency's Office of Solid Waste and Emergency Response, Economics, and Innovation, 2003.

[4]. Renieshaw, "Maintenance of equipment in the workplace", European Agency for Health and Safety at Work (EU-OSHA), 2011.

[5]. Jonathan E. Leightner, "Maintenance" Journal of Applied Economics, 2001,Vol. 4, No.1, pp.107-124.

[6]. Mekong Capital, "Introduction to Lean Manufacturing",1st edition, Vietnam, 2004.

[7]. Wikipedia, 2014, "Total productive maintenance", http://en.wikipedia.org/wik.

[8]. Proceedings of the World Congress on Engineering, "Total productive maintenance: A Study of Malaysian Automotive SMEs" 2012 Vol. III, July 4 - 6, 2012, London, U.K.

[9]. Steven Borris" Total productive maintenance ", McGraw-Hill - Companies, Inc., 2006.

[10]. Prasanth S. Poduval, Dr. V. R. Pramod, Dr. Jagathy Raj V. P, "Barriers In TPM Implementation In Industries" International Journal of Scientific\& Technology Research, Vol. 2, Issue 5, May 2013.

[11]. Prof PradeepKumar, Dr. K. V. M. Varambally , Dr. Lewlyn L.R. Rodrigues, "A Methodology for Implementing Total Productive Maintenance in Manufacturing Industries"International Journal of Engineering Research and Development, Vol. 5, Issue 2 Dec. 2012, PP. 32-39.

\section{BIOGRAPHIES}

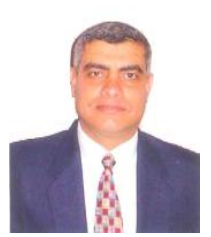

Mahmoud Mohamed A. Sayed: received PhD. From AL ZAHAR University, Egypt. Now, Head of mechanical engineering department in Canadian International College 